\title{
Strategic Planning Customer Experience using Predictive Analysis Indihome PT Telkom
}

\author{
Shandy Asri Achmad ${ }^{1}$, Pratami Anggina ${ }^{2}$, and Priyantono Rudito ${ }^{1}$ \\ ${ }^{1}$ School of Business and Management, Institut Teknologi Bandung, Bandung, Indonesia \\ ${ }^{2} \mathrm{PT}$ Telekomunikasi Indonesia, Bandung, Indonesia \\ e-mail:shandy_asri@sbm-itb.ac.id
}

\begin{abstract}
Telkom transformation paradigm by Innovating and disrupting the fast-changing industry is the main challenge right now. There is external challenging such as changing customer behavior and high performing Customer Experience (CX) focused industries that seeing customer and business growth. In PT Telkom itself, internal challenges there is a financial performance on a decreasing trend and for Net Promoter Score (NPS) is below best in class benchmark globally. The objective is elevating $\mathrm{CX}$ as a corporate strategic priority, engaging all stakeholders to achieve CX transformation. PT Telkom every year doing Net Promoter Score and Net Emotional Value (NEV) to measuring the loyalty of a firm's customer relationships and customer satisfaction that correlated with revenue growth. The author takes the model from secondary data from NPS and NEV Report from 2014 - 2018 of PT Telkom Indonesia, focused in Telkom Regional 3 West Java and assign relationship and satisfaction dimension and attribute. Using predictive analytics is a method that analyzing current and historical facts to make predictions about the future to determine an accurate strategy and can improve customer experience based on the appropriate level of correlation. From NPS and NEV report the dimensions and attributes are processed by predictive analysis using correlation and regression. The fact-finding that based on that analytics will be a strong correlation attributes that would become the key to strategic planning for a customer experience that in a lining with corporate strategy. The strong correlation attribute from this statistical processing is the installation process is long, friendliness of the technician, and ease of accessing points. Then the strategic planning for customer experience is from the result from predictive analytics combine with benchmarking with other telco's company to propose strategic program end-to-end customer journey and integrated to back end system, digitalization and digital ecosystem will be impacted and gave a result business and revenue.
\end{abstract}

Keywords-Net Promoter Score, Net Emotion Value, Customer Satisfaction, Customer Engagement, Strategy Transformation.

\section{INTRODUCTION}

L IKEWISE, in the telecommunications world, telecommunications are currently developing into information, media, edutainment and service. And the very rapid development is through the internet. Almost all Indonesian people use the internet for daily activities such as work, study, and other information. At present in August 2019 there are 215 million fixed broadband and wireless broadband users where the percentage of wireless broadband reaches $70 \%$ of total internet users based on marketing intelligent data Telkom. Fixed broadband users have different behavior. Customers want a product with affordable services but can provide the best service when purchasing or after sales service. The post-paid system implemented by the company makes this service have a high enough interaction so that the service stays of quality and is well maintained as offered. Therefore, customer experience is one of the issues currently discussed by management. In an era of rapidly developing customer experience, companies need to ensure that the customer is focus to all digital initiatives including the customer experience of the products and services provided. Consumers are looking for the next way user experience - personalized, interconnected, easy, fast, and smooth.

\section{A. Customer Experience}

Customer experience is defined as a combination of interactions from all different customer experiences at each point of contact in a customer-company relationship. This is a targeted effort on the part of the company to develop and maintain a good experience that is distinguished from competitors, consistent at every touch point and most importantly valued by customers. Meyer and Schwager (2007) define customer experience as the internal and subjective response customers have to any contact (direct or indirect) with a company. Customer experience is a holistic concept that encompasses every aspect of a company's offering 363 (Zomerdijk and Voss, 2009). According to (Kulbytè,2018) measuring customer experience is important because, if the customer are not satisfied, $13 \%$ of them will tell to 15 or even more people that they are unhappy. On the other hand, $72 \%$ of customers will share a positive experience with 6 or more people.

\section{B. Predictive Analytics}

Predictive analytics are data analytic classifications that focus on estimating possible future results in various industries based on past data and analytic methods that include statistical modelling and machine learning. Predictive analytics might make estimates with substantial accuracy. Predictive analytics allows organizations to use past and present data to project patterns and behavior in the next few days, months or years. For every organization, large or small, the ability to anticipate the future is the key to sustainable growth and sometimes even the very existence of an organization depends on it. Typically, data patterns are used in building models that track major trends after the data collected is analyzed. The results can then be used by decision makers to propose steps that must be followed to get the best results.

This is an evidence-based approach to making better decisions. This popular term only collects objective facts 
mainly and second related subjective data. The analysis is divided into three levels:

1. Descriptive. Descriptive research method aims to describe the character a variable, group or social phenomenon that occurs in the community (Martono, 2011: 17). Traditional customer loyalty and satisfaction metrics are mostly efficiency metrics (churn rate, service time,). The main focus here is cost reduction and process improvement. Descriptive customer analytics reveal and illustrate current and historical relationships and data patterns. This is the basis of analytic efforts for products and services. This includes, for example, customer segmentation; data mining for basic customer service patterns; and periodic reports.

2. Predictive analysis includes various techniques (statistics, modelling, data mining) that use current and historical facts to make predictions about the future based on probabilities and potential impacts. Among them are, the model used to increase the likelihood of improving service levels, customer satisfaction and an accurate service program according to customer needs. Predictive analytics is a classification of data analytics focused on forecasting the possibility of future outcomes in various industries based on past data and analytics methods which includes statistical modelling and machine learning. Predictive analytics may be able to create forecast with substantial accuracy. Predictive analytics, enables organizations use past and present data to project patterns and behaviours days, months or years ahead. For every organization, big or small, the ability to anticipate the future is the key to sustainable growth and sometimes even the very existence of the organization depends on it. Usually, data patterns are utilized in building a model that tracks key trends after the data collected has been analysed. The result can subsequently be used by decision makers to propose steps to follow for getting the best result.

3. Prescriptive analytics goes beyond predictions and outlines decision choices and optimizing services according to customer desires. This is used to analyse complex data to predict results, provide appropriate decision choices in a service program, and show alternative business impacts of each strategy implemented.

\section{Net Promoter Score and Net Emotion Value}

NPS is an effective method for measuring and controlling the level of satisfaction customers and calculate the level of customer loyalty in a Brand or company. NPS is measured on a scale of $0-10$ where: Promoter (9-10), Passive (7-8), Detractor (0-6). (Reichheld, 2011) decided to take the percentage of Promoter customer percentage and reduced the percentage of the Detractor. Passive category respondents are not counted in the formula. The result is a Net Promoter score. After the Net Promoter Score results are obtained, the NPS is divided into four categories namely NPS Star, NPS Leader, NPS Excellent, and NPS Good. NPS Star is a brand with the best NPS values in all categories, NPS Leader is a brand with values The highest NPS in each category, NPS Excellent is a brand with NPS positive minimum of $10 \%$ in each category, and NPS Good is a brand with NPS values are below $10 \%$ and are still positive in each category. The results of the NPS survey will be continued by detecting the Costumer Experience value which aims to see which customer experiences are truly satisfied through the moment of truth.

Net Emotional Value. NEV is a method to analyse experiences such as feeling, thinking, acting, and relating that will involve customers to make memorable relationships and connect them emotionally with the company or brand (Pine and Gil, 1998, Schmitt 1999). Without experience and emotional value, customers will lack encouragement, motivation, and trigger decisions and purchases. It is important for companies to know how they can connect with emotional customers (Surdak and King, 2015) In contrast to the NPS survey with one question, at the NEV survey considers various touch points (MOT) that show taste respondents about the experience they received such as happy or not happy from a product / service. Furthermore, the average of the touch points will be calculated at each the categories and results will be visible on which touch point makes the most memorable customer experience. NEV is obtained by finding the difference between emotions positive with negative emotional. Measurement of moment of truth varies depending on respective industry experience. NEV is a very simple calculation that takes average of the emotions which are :

a. Positive emotions : Happy, Pleased, Trusting, Valued, Cared for, Safe, Focused, Stimulated, Energetic, Interested, Exploratory, Indulgent.

b. Negative emotions : Stressed, Unhappy, Neglected, Hurried, Dissatisfied, Disappointed, Irritated, Frustrated, Dissatisfied.

\section{The Service Profit Chain Methodology}

This model starts with internal service quality which refers to the extent to which an organization is able to provide its employees with the type of quality support that will enable them to serve customers effectively which can be valued in the form of employee engagement. This will affect the quality of operations that will be provided by employees in each business process such as work responsibilities, work environment, training and clarity of orders High level of internal service quality will result in a level of customer satisfaction where service is designed and delivered to meet targeted customer needs, which will affect the level of churn, customer loyalty and customer retention. Loyal customers will be advocates for these products and services that will buy back products and services, referrals that will enhance a good brand reputation.

\section{E. Customer Journey}

The evolved complexity of the consumer decision-making journey and the difficulty and challenges posed when marketers attempt to map it can be seen on Figure 1. In particular, there is a compelling need for marketers to develop improved understanding of buyer behavior in the digital age so that meaningful interventions can be made at critical stages in the decision-making process. Many authors have highlighted the changes in consumer behavior that have occurred in the digital age but a widely accepted model has yet to emerge, although, a few valuable contributions such 


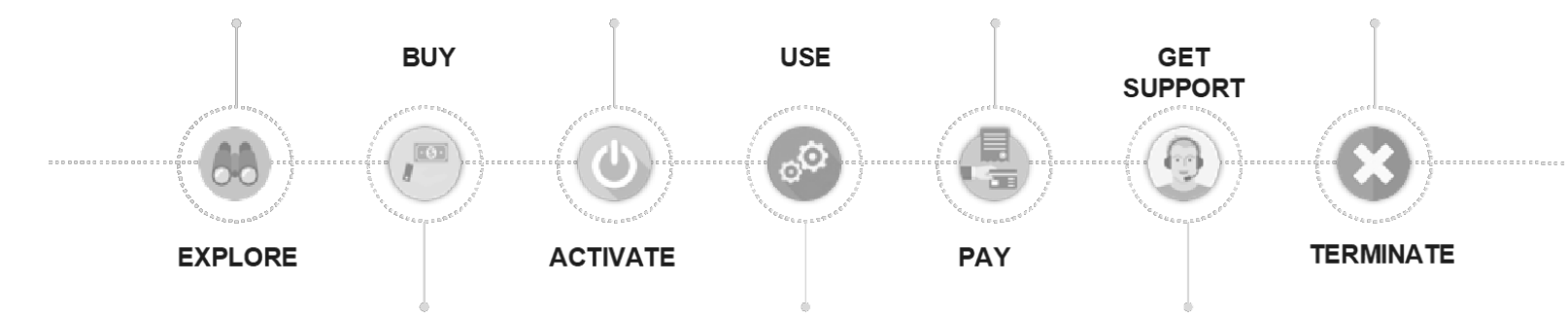

Figure 1. Digital Customer Journey.

Table 1.

Conclusion of Benchmarking

\begin{tabular}{|l|ll|}
\hline Company & \multicolumn{1}{c|}{ Customer Experience Strategy } \\
\hline Telstra & $:$ & Simplify product offering to eliminate customer pain \\
& $:$ & Drive value from the core based on infrastructure system \\
& $:$ & Empower mployec to serve customer \\
& Cost reduction and portfolio management program \\
\hline Globe & $:$ & Engaged customers and employees using Globe Community \\
& $\vdots$ & Consideration of consumer journey based on product and sales \\
& $:$ & User centered design \\
& Learning Globe Wonderful Service as employee service program \\
\hline KPN & $:$ & Best converged smart infrastructure \\
& $:$ & Focusing on profitable growth segments \\
& Accelerating simplification and digitalization \\
\hline
\end{tabular}

as, for example, Edelman (2010) have been made. Touchpoint interactions and Telkom way of working are digitized to best customer experience by fundamentally transform that will provide seamless experience across different touchpoint.

1. Explore : Company personalize services offered for each customer and allow easy access and selection

2. Buy : Company can digitize the buying process so that it is seamless and interactive

3. Activate : Company can make the installation process dramatically faster and more convenient

4. Use : Company can provide a superior quality of experience on our network, in terms of speed and reliability

5. Pay : Company can digitize the payment process so that it is significantly more convenient

6. Get Support : Company can empower customers to get support in an effective and efficient manner

7. Terminate : Company can retain customers or increase like hood for them to return.

F. Business Issues

In doing its business, where the customer is currently the main point-of-view for all companies, it is necessary to make an effort to increase customer experience based on customer journey. The existence of a higher customer experience points will certainly give positive things for the company, for example the company's competitive ability that other competitor will increase in the market because many customers became more loyal and satisfaction to company from the product itself. Manager Touch Point of TReg 3 stated that PT. Telkom Indonesia, through customer experience, expect process to be a way of company that can measure customer satisfaction in comprehensive way. And also IndiHome customers themselves can bring more feedback to company. However, companies need to know current customer experience from current customer to company (Personal Interview, 21/09/2019).
Delivering best customer experience transformation strategy for Indihome will become research focus. In company side, PT. Telkom Indonesia should define what customer journey point in critical and it drives actions to improvement and in customer side, company should know current customer satisfaction that will be effecting customer experience.

\section{METHOD}

\section{A. Research Methodology}

This study will use some customer experience based on data NPS and NEV to make statistic strategy for predict the future of customer experience program for making great satisfaction and loyal for customer.

B. Relationship Attribute of Net Promoter Score (NPS) and Net Emotional Value (NEV)

When assign customer satisfaction and loyalty dimension and attribute, researcher take the model from secondary data from NPS and NEV Report. Then the dimensions and attributes are processed into statistical processing as done in predictive analytics, using two analytic techniques, correlation and regression.

Correlation is a statistical to examines and measure that determines co-relationship or association of two variables that to represent linear relationship between two variables when regression examines how an independent variable that numerically related to the dependent variable. Correlation analysis aims to measure "how strong" or "degree of closeness", a relation that occurs between variables. Regression analysis is used to study and measure the statistical relationships that occur between two or more variables. These variables are the $\mathrm{X}$ variable (independent variable / influencing variable / known variable), and Y variable (dependent variable / influenced variable / unknown variable) 


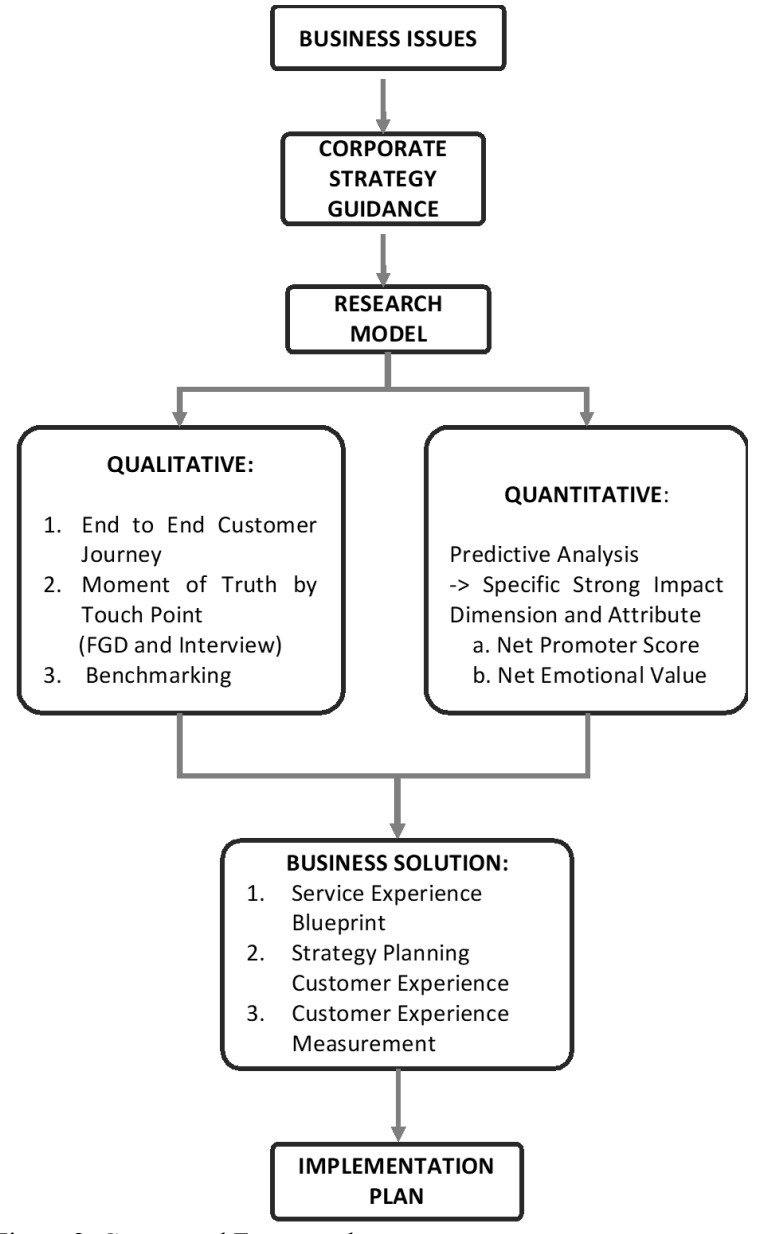

Figure 2. Conceptual Framework

Table 2.

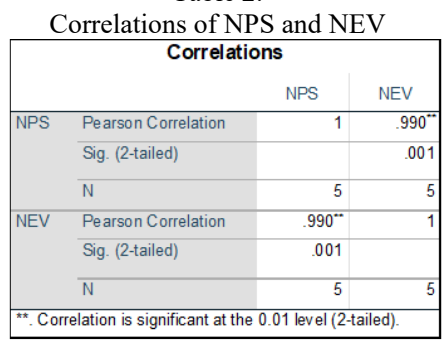

1) Interview and Field Check from Each Witel to Regional Strongest relationship make strong relationship between the variables, then the strongest attribute from NPS and NEV would appear for Consumer Care Telkom Regional 3 to identification with the existing condition and combine with the secondary data voice of customer and benchmarking withhold in interview to top management, fronliner, and Customer Care Manager in each Witel

2) Benchmarking to the other Telecommunication Company

Benchmarking to the other Telecommunication Company described on Table 1.

3) Planning Customer Experience Strategy Program

After Consumer Care TREg 3 create the report and send to Consumer Division in Consumer Assurance Unit (CA) to be analyzed and combined with corporate strategy and crosscheck to up level management by FGD. CA would create program by system that close loop inclusive with other metrics from all part of the organisations, as the source of CX
Table 3.

Regression Result for in NPS

\begin{tabular}{|c|c|c|c|c|c|c|}
\hline \multicolumn{7}{|c|}{ ANOVA $^{a}$} \\
\hline \multicolumn{2}{|c|}{ Model } & Sum of Squares & \multirow[b]{2}{*}{3} & \multirow{2}{*}{$\begin{array}{r}\text { Mean Square } \\
1.000\end{array}$} & \multirow{2}{*}{$\frac{F}{593.009}$} & \multirow{2}{*}{$\begin{array}{l}\text { Sig. } \\
.030^{\circ}\end{array}$} \\
\hline 1 & Regression & 3.000 & & & & \\
\hline & Residual & .002 & 1 & .002 & & \\
\hline & Total & 3.001 & 4 & & & \\
\hline \multicolumn{7}{|c|}{$\begin{array}{l}\text { a. Dependent Variable: NPS } \\
\text { b. Predictors: (Constant), PY4, B5, D5 }\end{array}$} \\
\hline \multicolumn{7}{|c|}{ Coefficients $^{2}$} \\
\hline \multirow{2}{*}{\multicolumn{2}{|c|}{ Model }} & \multicolumn{2}{|c|}{ Unstandardized Coefficients } & \multirow{2}{*}{$\begin{array}{l}\text { Standardized } \\
\text { Coefficients } \\
\text { Beta }\end{array}$} & \multirow[b]{2}{*}{$\mathrm{t}$} & \multirow[b]{2}{*}{ Sig. } \\
\hline & & B & Std. Error & & & \\
\hline 1 & (Constant) & 34.888 & 1.705 & & 20.463 & .031 \\
\hline & $\bar{D} 5$ & -.080 & .013 & -.558 & -6.178 & .102 \\
\hline & 85 & .405 & .349 & .090 & 1.161 & .453 \\
\hline & $\mathrm{PY} 4$ & .770 & .088 & .394 & 8.773 & .072 \\
\hline
\end{tabular}

Table 4.

Regression Result for in NEV

\begin{tabular}{|c|c|c|c|c|c|c|}
\hline \multicolumn{7}{|c|}{ ANOVA $^{\mathrm{a}}$} \\
\hline \multicolumn{2}{|c|}{ Model } & Sum of Squares & df & \multirow{2}{*}{\begin{tabular}{|r|} 
Mean Square \\
.013
\end{tabular}} & \multirow{2}{*}{$\begin{array}{l}F \\
96.006\end{array}$} & Sig. \\
\hline 1 & Regression & .040 & 3 & & & $.049^{\mathrm{b}}$ \\
\hline & Residual & .000 & 1 & .000 & & \\
\hline & Total & .040 & 4 & & & \\
\hline \multicolumn{7}{|c|}{$\begin{array}{l}\text { a. Dependent Variable: NEV } \\
\text { b. Predictors: (Constant), PY4, B5, D5 }\end{array}$} \\
\hline \multicolumn{7}{|c|}{ Coefficients $^{2}$} \\
\hline & & \multicolumn{2}{|c|}{ Unstandardized Coefficients } & $\begin{array}{l}\text { Standardized } \\
\text { Coefficients }\end{array}$ & & \\
\hline \multicolumn{2}{|c|}{ Model } & B & Std. Error & Beta & $\mathrm{t}$ & Sig. \\
\hline \multirow[t]{4}{*}{1} & (Constant) & 3.798 & .488 & & 7.777 & .081 \\
\hline & $\mathrm{D} 5$ & -.018 & .004 & -1.062 & -4.735 & .133 \\
\hline & $\overline{B 5}$ & .138 & .100 & .265 & 1.378 & .400 \\
\hline & $\mathrm{PY} 4$ & .047 & .025 & .210 & 1.883 & .311 \\
\hline
\end{tabular}

program actions in measurement cycle is along the way with the customer journey to indicate customer pain points on critical episodes. The impact of the actions reflected on the top down NPS. From CFU Consumer use case, NPS trends on critical episodes show slightly decrease.

C. Conceptual Framework

A conceptual framework is is a coherent system consisting of fundamental objectives and concepts that are interconnected, and a concept of thinking from starting to find business issues to implementing solutions which concept use in this research is elaborate

A conceptual framework is is a coherent system consisting of fundamental objectives and concepts that are interconnected, and a concept of thinking from starting to find business issues to implementing solutions which concept use in this research is elaborate in Figure 2.

Firstly, company observations are based on company data and define business problems based on reality and major business problems. Based on Corporate Strategy Guidance as a guide in research to fit the company's goals to be achieved based on initiatives to be carried out in the current year. One of the strategy is Embracing Best in class Digital Customer Experience. This step is done to strengthen the solution based on the problems found.

Secondly, for research model is a model that brings together all the data that have been studied previously. This research model will be a guideline for this research. There is two side based on Predictive analysis from historical data and Company current condition. Predictive analysis is used to analyze the relationships in historical information to predict some desired results based on historical data of Net Promoter 
Table 5 .

\begin{tabular}{|c|c|}
\hline Quentiona & Answers \\
\hline $\begin{array}{l}\text { What do you think } \\
\text { about consumer } \\
\text { journey for Indithoene } \\
\text { eurrently? }\end{array}$ & 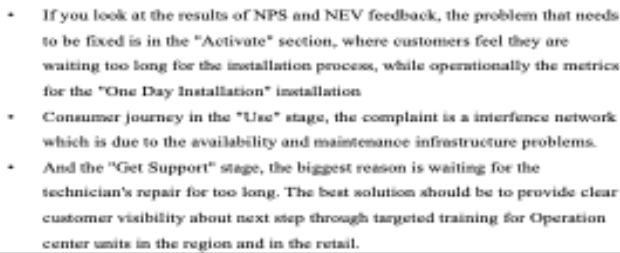 \\
\hline $\begin{array}{l}\text { What mattern if the } \\
\text { eustomer pain point is } \\
\text { resolved? }\end{array}$ & 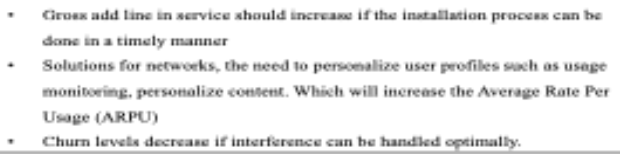 \\
\hline $\begin{array}{l}\text { What should be } \\
\text { resalved first to } \\
\text { improve the customer } \\
\text { pain poim? }\end{array}$ & 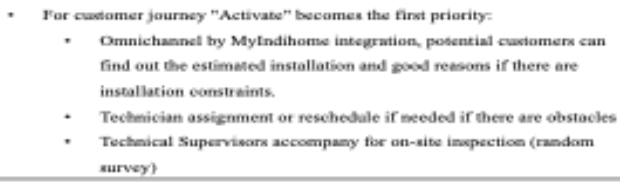 \\
\hline $\begin{array}{l}\text { What should be } \\
\text { remolved flint to } \\
\text { improve the customer } \\
\text { pain poine? }\end{array}$ & 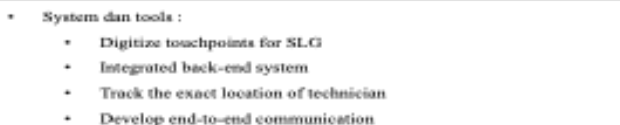 \\
\hline
\end{tabular}

\begin{tabular}{|c|c|}
\hline Questions & Anrwern \\
\hline $\begin{array}{l}\text { Are improvements } \\
\text { needed in termis of } \\
\text { people? }\end{array}$ & 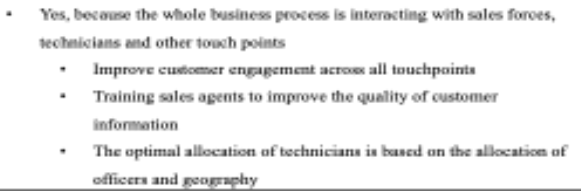 \\
\hline $\begin{array}{l}\text { What is the direot } \\
\text { impact if the eusiomer } \\
\text { pain poins are } \\
\text { resolved? }\end{array}$ & 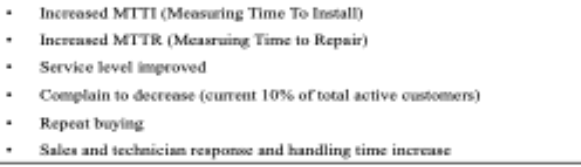 \\
\hline $\begin{array}{l}\text { What is the business } \\
\text { impact if this is } \\
\text { resolved? }\end{array}$ & 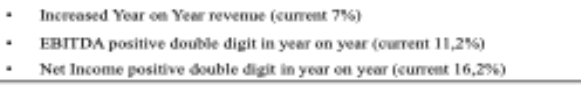 \\
\hline $\begin{array}{l}\text { What is the business } \\
\text { result if this is } \\
\text { rewalked? }\end{array}$ & $\begin{array}{l}\text { - Transformational goels will be achieved: } \\
\text { - Placing abed where our customers are going } \\
\text {. More efficient and effiective and adding value doppite every activity } \\
\text {. Giving Wow Cuatumer experience }\end{array}$ \\
\hline
\end{tabular}

Table 6.

List of Questions and Answers from New Customer Indihome

\begin{tabular}{|c|c|}
\hline Question & Answer \\
\hline $\begin{array}{l}\text { Why did you choose } \\
\text { Indihome for internet } \\
\text { services? }\end{array}$ & $\begin{array}{l}\text { - The service is as needed } \\
\text { - Services are available in a residential environment } \\
\text { - Info from relatives }\end{array}$ \\
\hline $\begin{array}{l}\text { How did you find out } \\
\text { information } \\
\text { Indihome? }\end{array}$ & $\begin{array}{l}\text { - Information through sales agents who are in the } \\
\text { neighborhood }\end{array}$ \\
\hline $\begin{array}{l}\text { What touchpoint do you } \\
\text { subscribe to Indihome? }\end{array}$ & $\begin{array}{l}\text { - Request requests through sales agents } \\
\text { - Data input via MyIndihome }\end{array}$ \\
\hline $\begin{array}{l}\text { Are there any difficulties } \\
\text { during request requests? }\end{array}$ & $\begin{array}{l}\text { - Installation that takes too long } \\
\text { Differences in information from sales agents and } \\
\text { technicians regarding Indihome's use and features } \\
\text { and payment for the first bill } \\
\text { - Less informative when technicians do the installation }\end{array}$ \\
\hline $\begin{array}{l}\text { Are there advantages } \\
\text { during the request process? }\end{array}$ & $\begin{array}{l}\text { - The requested service is appropriate } \\
\text { There is no cash payment to the sales force or } \\
\text { technicians }\end{array}$ \\
\hline $\begin{array}{l}\text { Are you satisfied with } \\
\text { Indihome's services }\end{array}$ & - Satisfied, for internet speed and IPTV is good. \\
\hline $\begin{array}{l}\text { What do you expect of } \\
\text { Indihome services? }\end{array}$ & $\begin{array}{l}\text { - Accurate and aligned information from the initial } \\
\text { offer to installation } \\
\text { - Ease of payment and detailed billing information } \\
\text { - Information on internet data usage }\end{array}$ \\
\hline
\end{tabular}

Score and Net Emotional Value of the customer of Indihome that will be gave a spesific result for the relationship.

In the Business Solution phase, the strategy will be formulated using customer experience modelling. These strategy will become the reference for represent and systematize customer experience to make service design that combine multidisciplinary. Besides, the customer experience modelling through interviews, and focus group discussion.

Finally after defining the strategy, that gave strategy program for customer experience that have primary goal is to give solution to the issues and inefficiencies along the existing customer journey. The last phase is the implementation plan of the proposed customer experience model and its strategy program for customer experience.

\section{RESEARCH METHODOLOGY}

A. Business Solution

1) Relationship Attribute of Net Promoter Score (NPS) and Net Emotional Value (NEV)

Based on the calculation results that can be seen in Table 2, it was found that the Sig. (2-tailed) between NPS and NEV that is equal to $0.001<0.05$. This value indicates that there is a significant correlation between NPS and NEV. In addition, when viewed based on the Pearson correlation (R) value of $0.99>0.878$ ( $\mathrm{R}$ table with $\mathrm{N}=5$ ), it can be seen that there is a correlation between NPS and NEV.

Then the Pearson correlation test was performed for each attribute contained in the NPS and NEV. Based on 53 existing attributes, only three attributes that have a high correlation with NPS and NEV are the installation process is long, 
Table 7.

Interview Result from Current Customer Indihome

\begin{tabular}{|c|c|}
\hline No & Answer \\
\hline 1 & $\begin{array}{l}\text { Most of them are using Indihome almost more than } 6 \text { month to do internet } \\
\text { activities such as working, assignment, and other entertainment activities } \\
\text { (watch film, video, social media) }\end{array}$ \\
\hline 2 & $\begin{array}{l}\text { Word that associated with Indihome : useful, unstable, long time handling, } \\
\text { fast internet, competitive price, different information }\end{array}$ \\
\hline 3 & Price and service avaibility for the interviewee when deciding to use Indihome \\
\hline 4 & $\begin{array}{l}\text { According to them after sales quality is important, starting from the beginning } \\
\text { of the offer that is information that is appropriate and clear and easy to find } \\
\text { anywhere. And handling complaints is fast and time is clear. }\end{array}$ \\
\hline 5 & $\begin{array}{l}\text { The expectation to Indihome: maintaining service quality, information is } \\
\text { available anywhere, diverse content }\end{array}$ \\
\hline 6 & $\begin{array}{l}\text { They prefer to come to Plasa Telkom if reporting service constraints because } \\
\text { it is more reliable than through MyIndihome and } 147 \text { because information is } \\
\text { sometimes inaccurate and unfinished solution }\end{array}$ \\
\hline 7 & $\begin{array}{l}\text { The interviewees are willing to pay more to get bundling services like Spotify, } \\
\text { Netflix, online learning, or any others digital platform and other service } \\
\text { improvements if informed earlier }\end{array}$ \\
\hline
\end{tabular}

Table 8 .

Customer Journey Moment of Truth

\begin{tabular}{|c|c|c|c|c|c|c|}
\hline EXPLORE & BUY & ACTIVATE & USE & PAY & SUPPORT & TERMINATE \\
\hline $\begin{array}{ll}\text { - Open Table } \\
\text { by Sales } \\
\text { Force } \\
\text { - Mylndihome } \\
\text { - } \text { Web } \\
\text { Indihome } \\
\text { - } \text { Plasa Telkom } \\
\text { - Inbound \& } \\
\text { Outbound } \\
147 \\
\text { - Social Media }\end{array}$ & $\begin{array}{l}\text { - Offline } \\
\text { registering } \\
\text { by Sales } \\
\text { Force } \\
\text { - Online } \\
\text { system } \\
\text { registering } \\
\text { Mylndihome } \\
\text { and Sobat } \\
\text { Indihome }\end{array}$ & $\begin{array}{l}\text { - } \text { Order } \\
\text { Activate for } \\
\text { Technician } \\
\text { - Installation } \\
\text { in customer } \\
\text { home } \\
\text { - Schedule by } \\
\text { system } \\
\text { - Installation } \\
\text { process } \\
\text { - Friendly } \\
\text { technician }\end{array}$ & $\begin{array}{l}\text { - Package as } \\
\text { request } \\
\text { - Connection } \\
\text { stability } \\
\text { - Service } \\
\text { Quality }\end{array}$ & $\begin{array}{l}\text { - Accuracy in } \\
\text { bill amount } \\
\text { - Ease to } \\
\text { accessing } \\
\text { billing } \\
\text { information } \\
\text { - Availability } \\
\text { payment } \\
\text { method and } \\
\text { points }\end{array}$ & $\begin{array}{l}\text { - Service } \\
\text { complaint } \\
\text { - Service } \\
\text { request } \\
\text { - } \text { Friendlines } \\
\text { s complain } \\
\text { handling } \\
\text { technician } \\
\text { - Response } \\
\text { speed } \\
\text { - Technician } \\
\text { skill }\end{array}$ & $\begin{array}{l}\text { - Easy to } \\
\text { terminate } \\
\text { - Solution for } \\
\text { terminate }\end{array}$ \\
\hline
\end{tabular}

friendliness of the technician, and ease of accessing points. All three of these attributes have a Pearson correlation value greater than 0.878 and the Sig. (2-tailed) is smaller than 0.05

\section{2) Net Promoter Score}

The requirements for Pearson Correlate are seen from the distribution table r. Because of the author used 2014-2018 (5 years) for samples, the value must be more than 0.878 (minimum R square condition for strong relationship attribute) for strong correlation in Table 3.

Based on appendix 1. obtained attributes that have a value of $\mathrm{R}>0.878$ with NPS that is poor customer service, consisting of services that are not needed, the installation process is long, friendliness of the technician, and ease of accessing points. However, only the attributes of the installation process is long, friendliness of the technician, and ease of accessing points have an exchange rate with the NPS and NEV, so a regression test for the new attribute will be carried out.

\section{3) Net Emotional Value}

Same as NPS, the requirements for Pearson Correlate are seen from the distribution table $\mathrm{r}$ value must be more than 0.878 (minimum $\mathrm{R}$ square condition for strong relationship attribute) for strong correlation for NEV.

It is found that the attributes that have a value of $\mathrm{R}>0.878$ with NEV are the installation process is long, friendliness of the technician, schedule as desired, ease of accessing points, information services, and availability of disturbance complaint services. However, only the installation process is long, friendliness of the technician, and ease of accessing points have a correlation value with NEV and NPS, so a regression test for these three attributes will be carried out.

Based on Table 4, multivariate regression results obtained with the value of Sig. of $0.049<0.05$ so that the three attributes can affect NEV. Therefore the regression equation obtained is

$\mathrm{Y}=3.798-0.018 \mathrm{X} 1+0.138 \mathrm{X} 2+0.47 \mathrm{X} 3$

$\mathrm{Y}=$ Net Emotional Value

$\mathrm{X} 1=$ installation process is long

$\mathrm{X} 2=$ friendliness of the technician

$\mathrm{X} 3$ = ease of accessing points

B. Internal Focus Group Discussion

Internal focus group discussion is done by gathering some of employees who relate to the customer experience for Indihome in CFU Consumer, Unit Consumer Care TREg 3. The FGD consist of Operation Senior Manager Consumer Care TREg 3, Manager Touch Point, Manager Retention and Loyalty, 5 Assistant Manager of Consumer Care from Witel (Bandung, Bandung Barat, Cirebon, Sukabumi, Karawang, Tasikmalaya). The FGD start with the questions of their opinion about current customer journey and customer 


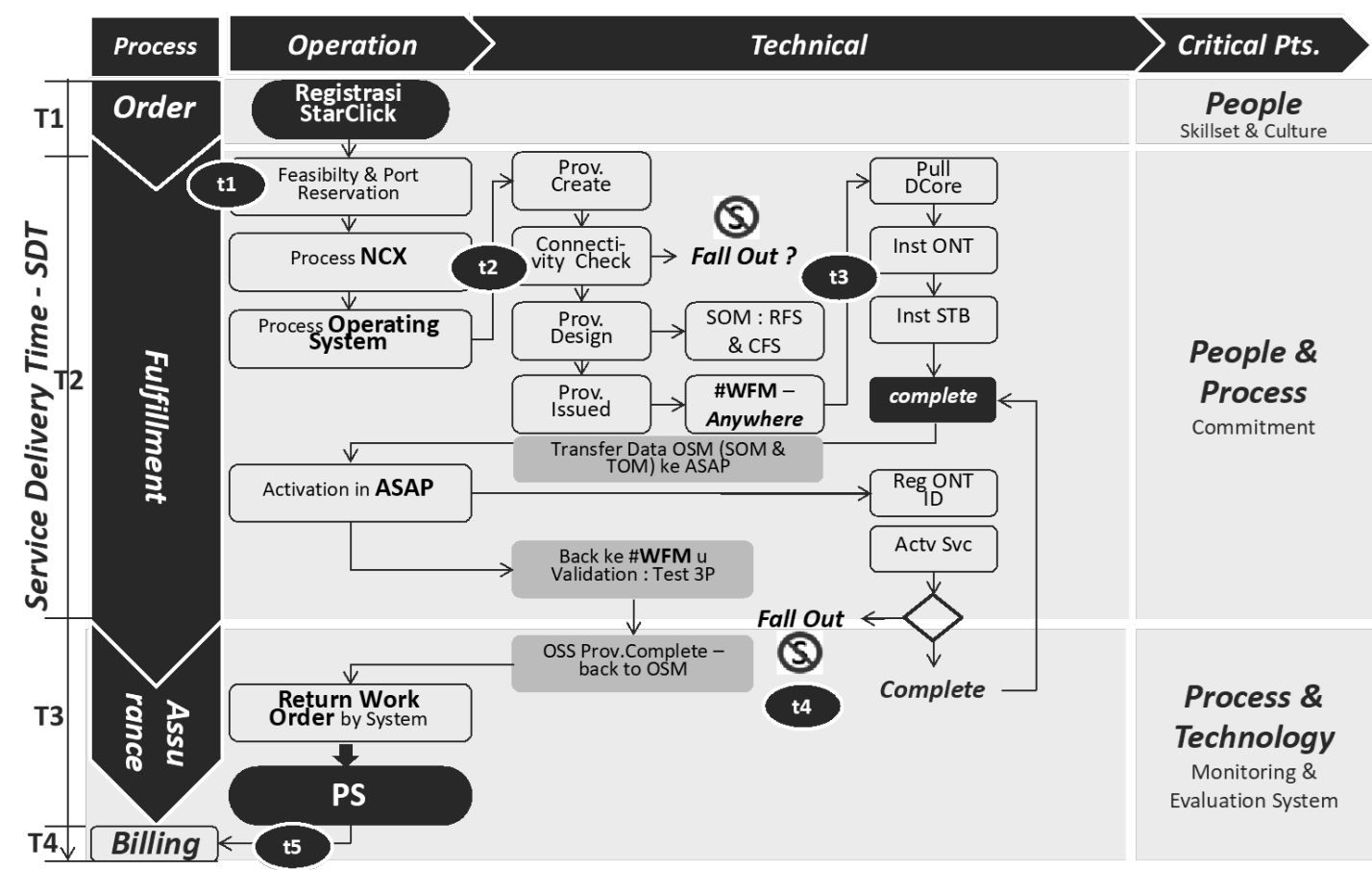

Figure 3. Service Experience Blueprint for Fulfilment Service.

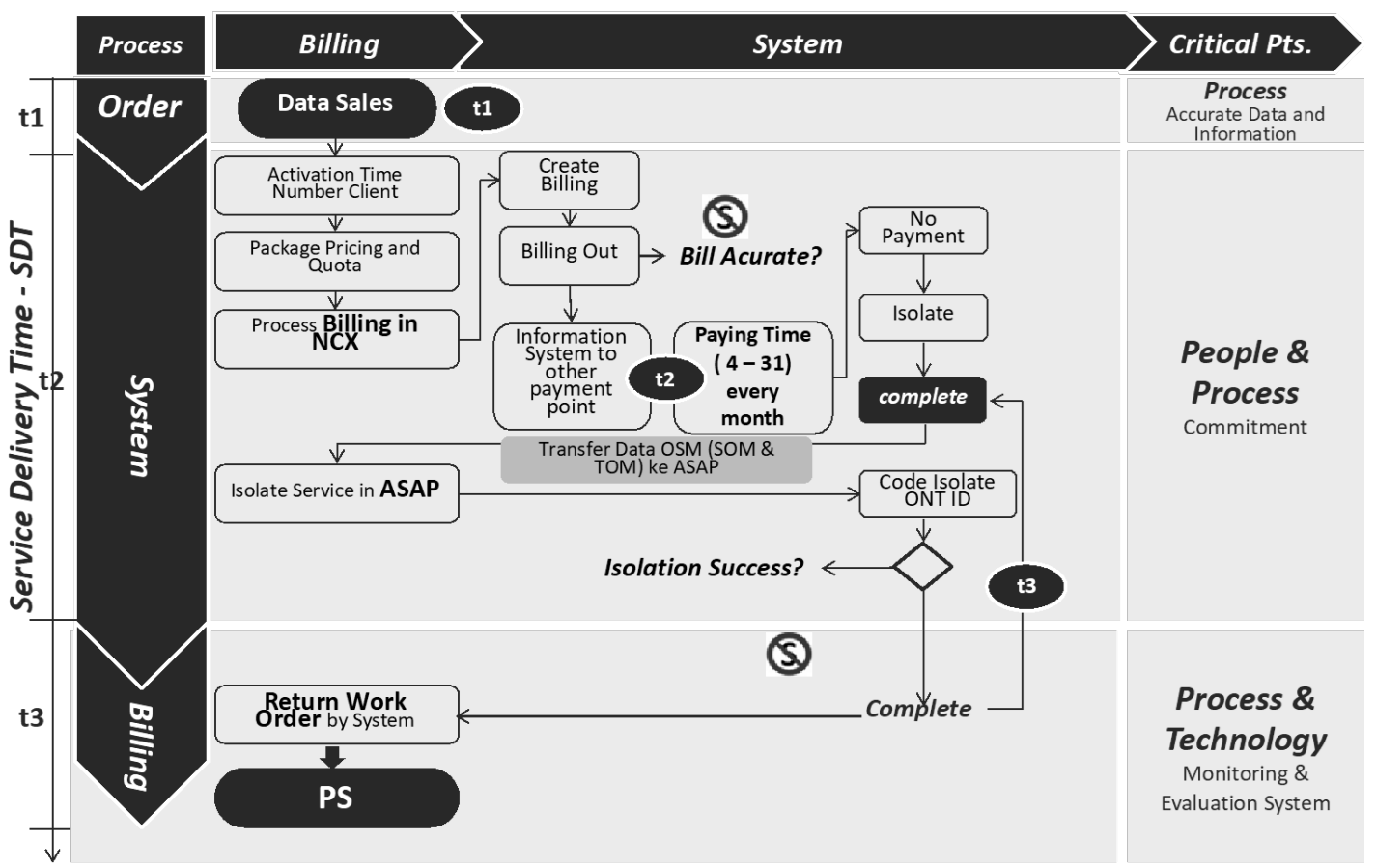

Figure 4. Service Experience Blueprint for Billing Support Service

experience, and from the answer lead to the another questions. The resume of the FGD are shown in Table 5.

\section{Interview with customers Indihome}

Interview with the new customers and current customer with a minimum subscription period of 6 months who use Indihome service to understand the need, wants and satisfaction Indihome service. In this research, the interview is done by interviewing the new customer in Table 6, and current customers in Table 7.

For current customers, researcher do the interview to some people with different background who are actively a Indihome users. The interviewee consists of high school students, S1 college, S2 college and workers. The result of the interview are shown on Table 7.

\section{Strategic Planning Initiative}

For the further development of Telkom customer care of Indihome, with the aim of customer enthusiasm as part of the CEM initiative, the design elements of the customer. Proven touchpoints and the customer journey: In the The core idea is considered from the customer perspective, in what form the customer contacts the brand and how the individual brand experiences come together to form a complete brand or support perception. In four steps, the process of achieving customer enthusiasm according to the plan along the 


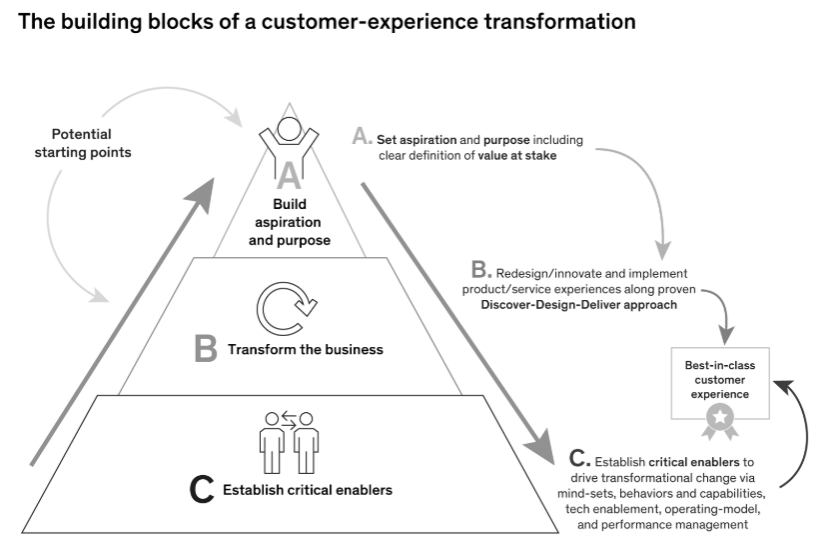

Figure 5. The Building Block of Customer Experience Transformation

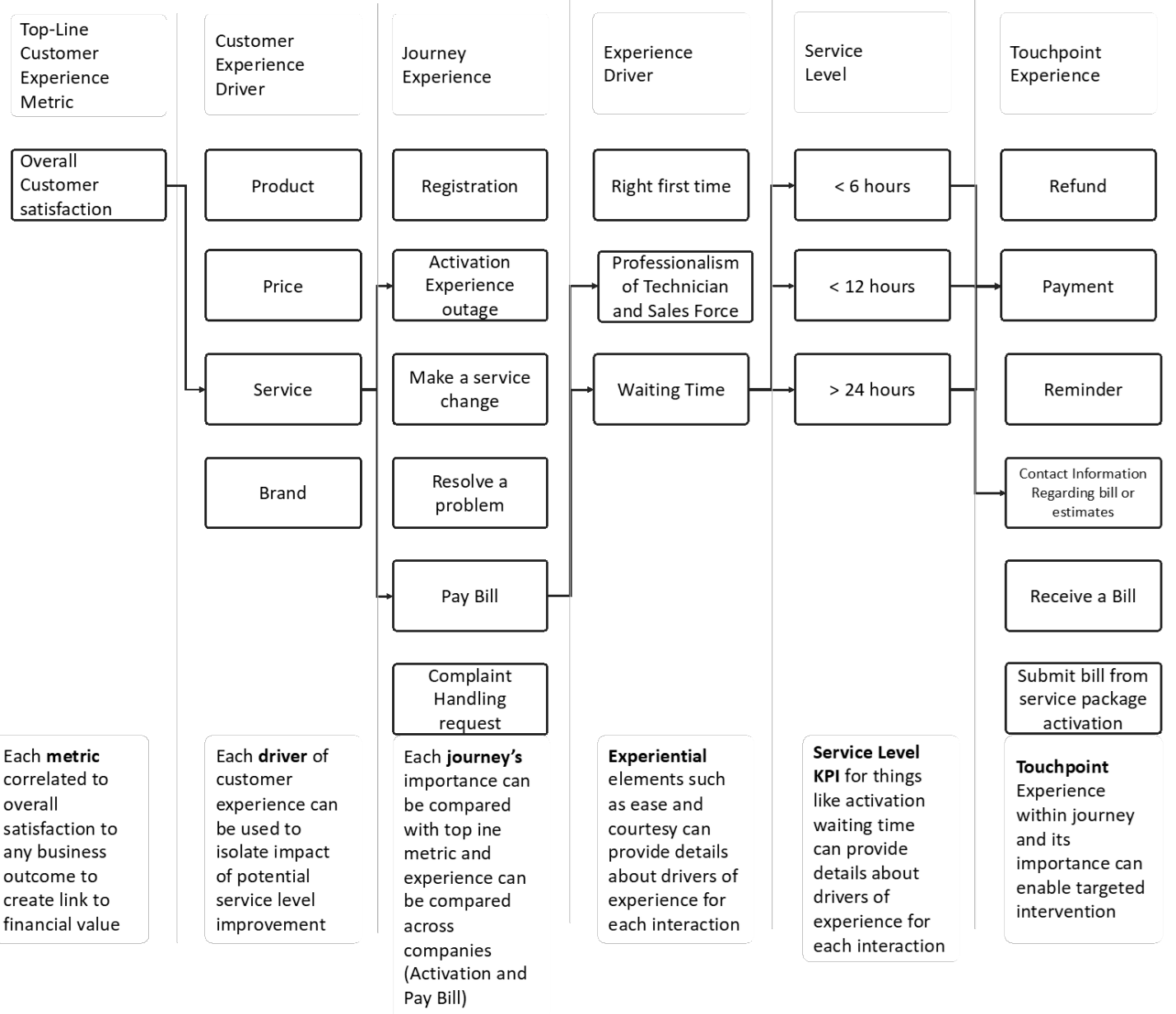

Figure 6. Linkage measuring consumer experience throughout call to utility company.

customer journey implemented at Indihome as part of the CEM initiative):

1. The first step was to record the got in touch with the customer and the customer side. Customer journey across contact points. At the same time there were first indications of the time and content optimization of contact points. Over 7 millions current and former customers and other competitive brands were in Indonesia especially in West Java and asked about their individual support experiences about internet and the competition brands. In the meantime, there is an overall view of the customer contact points (the "Customer Touchmap") for the most important sales markets. Indihome now need to complete picture of through which contact points and in the quality of the Indihome product and service is experienced along the customer journey.

2. In the second step, the actual customer journey was compared with the customer expectations: not at every customer contact point are customer needs similar. Extreme examples are the breakdown, at who is focused on rapid and timely replacement internet speed, while when subscribe for Indihome, detailed advice with internet speed, content and value added. At the same time, the external benchmark and from customer market 

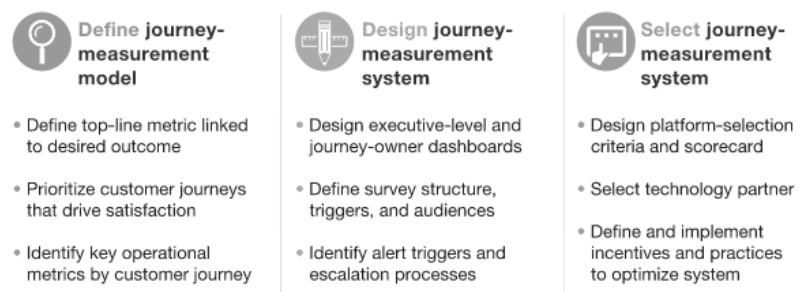

Figure 7. Selecting a Journey Measurement System in Three Step process.

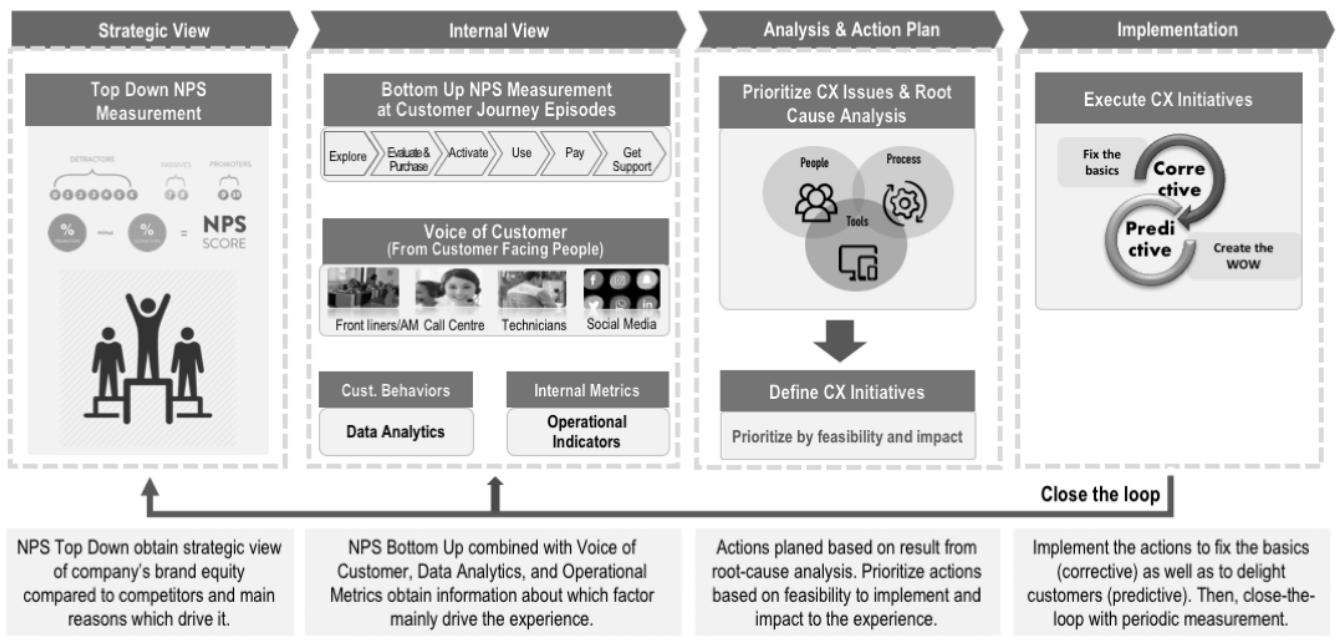

Figure 8. Close The Loop: Beginning and Ending With The Customer in Mind.

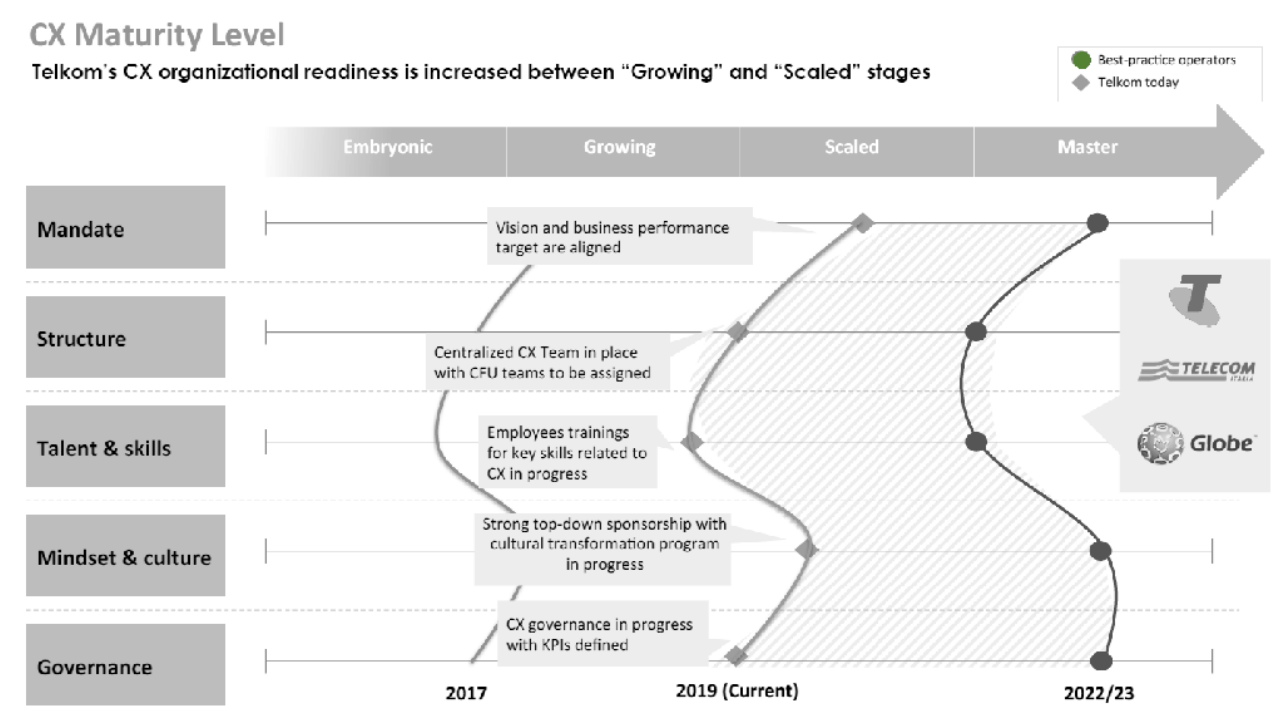

Figure 9. Moving The Right Path towards CX Excellence.

research (step 1) suggestions other innovative customer contact points and support processes with enthusiasm. This alone gave valuable insights: The almost complete overview of all customer contact points showed where and how - from a customer perspective, on the other hand, were very positive, according to customer feedback high degree of customization of customer communication for selected customer groups. From the comparison of the current customer journey (Step 1) with the customer expectations (Step 2) resulted prioritization of customer contact points and customer care processes, their further development or, if necessary first-time establishment of particularly high satisfaction and ideally there was potential for enthusiasm.

3. In the third step, the potential was identified. Step 2 implemented in action and activity plans: On the one hand, the further development of individual contact points was carried out based on the findings of the second step. On the other hand, there was potential for optimization the further development of the interaction of customer contact points or the new development of parts of the Customer journey: not the single customer contact point, but entire sections along the customer journey were the focus. For this purpose, the so-called MyIndihome. 
4. Also, for the implementation of the action plan the fourth step was and is the commitment of all areas and markets crucial. The individual measures were developed together with the participating division or promoted by these on their own initiative, after by the preparatory work in step 3 was given a corresponding impetus has been. In parallel, a measuring instrument was set up to the effectiveness of measures based on key indicators to investigate. These have been and will be in the context of a Scorecard reports (yearly doing by Telkom). A top management reporting for the CEOs of the individual national companies as well as the member The Board of Management for Sales and Marketing is supplemented by detailed reports for the individual functional areas. Overall, it is the "Customer Experience Management" initiative, in which the above four. Steps are bundled together to create a continuous activity.

\section{E. Service Experience Blueprint (Moment Of Truth)}

The SEB method was developed specifically for designing multi-interface service experiences. SEB builds on existing methods, joins service management contributions and software engineering to create a unifying method for overcoming the entry of technology into services. SEB enables the integrated design of multi-interface services, enhancing the advantages of each channel to enhance the overall customer experience. Table 8 explain about MoT (Moment of Truth) from customer journey in Indihome product services. Based on 2.2.4. Customer journey, there is 7 step of customer journey that indicates the MoT of every stage

The following is SEB from Fulfilment Service where there are 5 points identified to be 5 main points on Figure 3:

1. t1: When customers register they need to do feasibility and port reservation or network availability. This process is time consuming and there must be a matching system data and field data.

2. t2: The process of pushing data to a system where the implementation of a new system that is NCX was only applied in mid-2019 is still an obstacle due to the process of migrating data from the previous system

3. t3: After the registration process is systemically successful, work orders for technicians are sent via WFM according to the technicians' conditions and work schedules. Constraints that often occur are installation rescheduling, installation constraints, conflicting schedules

4. t4: After installation, the possibility of fallout or error is still high, due to the need for a system that is systemically pushing to perform PS (Put in Service) or on service

5. t5: PS data or on service will enter the billing system which will adjust to the type of package and service used. The obstacle is that the system has not been well integrated. Where there is still a manual system

The following is SEB from Billing Support Service where there are 3 points identified to be 5 main points on Figure 4:

a. t1: Sales data for the current month will go to the billing system where this system will bill the PS customers according to the activation date with the value of the prorated package that will be different from the following month's billing. At this point the most crucial. Because when the offer and when the activation will differ the information provided, an integrated system is needed here because customers need to be given information openly and in detail about their invoices.

b. t2: The bill will come out every 4th of the month. This bill will be integrated into any online payment system. The obstacle at this point is the existence of a system that is not automatically integrated and only makes payments without a back end information system informing the system at Telkom that the customer has already made a payment. Because this system is through a subsidiary's system that requires time for integration.

2. t3: If the customer is informed not to make a payment until the time limit specified, the service will be isolated. At this point it is very crucial, whether the isolator will succeed or not depends on the NCX system which is still in the process of migrating services and information systems.

\section{F. Implementation Plan \\ 1) Customer Experience Transformation}

McKinsey \& Company found that when companies have clear view of the building block and reference throughout the transformation journey to make better decision and coordinate more efficiently can be seen on Figure 5.

a. Establish critical enablers

Customer experience is an excellent starting point for digital transformation because it determines satisfied customers and will also resolve many of the inefficiencies inherent in a product and service. Focus on value and bottomline value delivery is also important, such as the ability to generate extensive excitement in the organization.

b. Transform the business

Designing new experiences helps employees connect with the value they create for customers, unite teams across functions, and function as a shared language that allows departments to communicate more easily. Future customer experience can also be designed to create a guide to guide the organization on a destination-based trip.

c. Build aspiration and purpose

Effective customer-experience transformation requires a clear vision and articulation of customer-centered and ambitious goals. Metrics are very important for understanding customer needs and performance levels, but leaders also need to take a holistic view of end-to-end customer experience. A typical transformation can take two to three years and depends on attracting or increasing talent to maintain the continuous improvement needed for success. (Building blocks A, C.)

\section{2) Customer Experience Measurement}

It's important to evaluate systems based on how well company can carry out measurement strategies. In addition, three strategic criteria are also worth considering can be seen on Figure $6-7$.

a. Flexibility. Some system providers can make changes to survey questions and dashboards in minutes, while others take days or weeks, or leave them to you to find out. Think carefully about the frequency you expect to make changes 
and the level of your resources to make these changes yourself.

b. Scalability. Choose a system that has been tested in a broad spectrum of complex multinational environments with proven capacity to scale in response to the needs of your organization.

c. Costs. Companies regularly face tight budget pressure or have a cost-conscious culture that manifests itself in a doit-yourself mindset. If your approach to the customer experience is serious, beware of all-dancing, all-dancing measurement systems that are much cheaper but may fail to have the desired effect. Weigh the return on investment, not just the lowest cost.

3) Innovation Solution

Company need to innovative 'close the loop' measurement framework helped us to not just identify, but also resolve customer pain points, using NPS along with other metrics from all parts of the organization in Figure 8. It looks at measurement and root cause analysis every stage, from strategic planning, to implementation. This measurement cycle runs in parallel with the customer journey, to fix the basics (corrective) as well as to delight customers (predictive).

So that we see successful impact on:

1. NPS improvement as our voice of the customer metric.

2. Impact of NPS on our financial metrics.

This is monitored and reviewed in our weekly top management meeting.

\section{4) Business Impact and Result}

Telkom are now in a position to be able to roll out our blueprint on a nationwide scale in Figure 9. And in telecommunication wider industry, Telkom have seen Indihome CX achievements move Telkom from 'growing' to 'scaled' in our CX organisational readiness, benchmarked against best practice operators. It demonstrates that we are well on the way to achieving our transformational goals:

a. Digital - to digitise every part of Telekom's business, placing us ahead of where our customers are going.

b. Lean - to be more efficient and more effective, adding value through every activity.

Customer Experience - to put our customers' needs and expectations at the heart of everything company do.

\section{CONCLUSION}

Customer enthusiasm should be strategically and organizationally anchored in the company as a goal and through a systematic Customer experience management can be implemented sustainably. It is important that the (critical) contact points from the customer's point of view to optimally design along the customer journey. Telkom can do this. Best practices from other industries. Optimization potential point out that it is based on your own business context adapt applies. Ultimately, customer enthusiasm does not mean short-term to be achieved, but requires continuous efforts to convert customer enthusiasm into sustainable brand enthusiasm. A company can join the Organization of customer experience management in terms of processes based on the classic PDCA cycle.
1. Customer enthusiasm is a key entrepreneurial. Objective to achieve customer loyalty.

2. The design of excellently perceived plays. Customer experiences with every brand contact as possible Triggers customer enthusiasm play a central role.

3. It is important to optimize the customer journey, and above all align the critical contact points in the best possible way towards customer expectations and needs and towards each other vote.

4. Best practices from other industries provide valuable impulses and ideas for moments of enthusiasm.

5. Customer enthusiasm is equal to customer satisfaction continuously monitor and control.

\section{REFERENCES}

[1]. Johnston, R. \& Kong, X. (2011). The customer experience: A roadmap for improvement. Managing Service Quality, 21(1), 5-24.

[2]. Martono, N. 2017. Metode penelitian kuantitatif: Analisis Isi dan Analisis Data Sekunder

[3]. Reichheld, F.F. 2011. The Ultimate Question 2.0 (Revised and Expanded Edition): How Net Promoter Companies Thrive in a Customer-Driven World,

[4]. Sandstrom, S. \& Edvardsson, B. (2008). Value in use through service experience. Managing Service Quality, 18(2), pp. 112-26.

[5]. Schmitt, B. (2003). Customer experience management: a revolutionary approach to connecting with your customers. New York: Wiley, pp. 9-12

[6]. Shaw, C. \& Ivens, J. (2005). Building Great Customer Experiences. Basingstoke: Palgrave Macmillan

[7]. Ashman, R., Solomon, M.R. and Wolny, J. (2015) An old model for a new age: Consumer decision making in participatory digital culture. Journal of Customer Behaviour [online] 14 (2) pp. 127-146

[8]. Banyte, J. and A. Dovaliene, 2014. Relations between Customer Engagement into Value Creation and Customer Loyalty. Procedia Social and Behavioral Sciences, 156, 484-489.

[9]. Bolton, R. N., J. R. Mccoll-Kennedy, L. Cheung, A. Gallan, C. Orsingher, L. Witell and M. Zaki, 2018. Customer experience challenges: bringing together digital, physical and social realms. Journal of Service Management, 29(5), 776-808.

[10]. Gentile, C., Spiller, N., and Noci, G. 2007. How to Sustain the Customer Experience: An Overview of Experience Components that Co-Create Value with the Consumer. European Management Journal, 25(5), pp. 295-410.

[11]. Gentile, C., N. Spiller and G. Noci, 2007. How to Sustain the Customer Experience: An Overview of Experience Components that Co-create Value With the Customer. European Management Journal, 25(5), 395-410. Available from: https://doi.org/10.1016/j.emj.2007.08.005

[12]. Homburg, C.,Koschate, N.,Hoyer, W. D. 2005. Do Satisfied Customers Really Pay More? A Study of the Relationship between Customer Satisfaction and Willingness to Pay, in: Journal of Marketing, 69, 2, pp. 84-96.

[13]. Johnston, R. and X. Kong, 2011. The customer experience: a roadmap for improvement. Managing Service Quality, 21(1), 5-24. Available from: http://dx.doi.org/10.1108/09604521111100225

[14]. Klaus, P. and S. Maklan, 2013. Towards a better measure of customer experience. International Journal of Market Research, 55(2), 227-21. Available from: http://dx.doi.org/10.2501/IJMR-2013-021

[15]. Klaus, P., 2014. Measuring Customer Experience: How to Develop and Execute the Most Profitable Customer Experience Strategies. London: Palgrave-Macmillan. ISBN 978-1-137-37546-9

[16]. Maklan, S. and P. Klaus, 2011. Customer experience: are we measuring the right things? International Journal of Market Research, 53(6), 771-23. Available from: http://dx.doi.org/10.2501/IJMR-53-6771-792

[17]. McColl-Kennedy, J. R., Gustafsson, A., Jaakkola, E., Klaus, P., Radnor, Z. J., Perks, H., Friman, M. (2015). Fresh perspectives on customer experience. The Journal of Services Marketing, 29(6/7), pp. $430-435$

[18]. Meyer, C. \& Schwager, A. (2007). Understanding customer experience. Harvard Business Review, 85(6), 137. 
The $1^{\text {st }}$ International Conference on Business and Engineering Management (IConBEM 2020)

February $1^{\text {st }} 2020$, Institut Teknologi Sepuluh Nopember, Surabaya, Indonesia

[19]. Schmitt, B. 2010. Experience Marketing: Concepts, Frameworks and Consumer Insights, Vol. 5, No.2, pp. 55-112 [2] W.-K. Chen, Linear Networks and Systems.Belmont,CA: Wadsworth, 1993, pp. 123-135.

[20]. Schwager, A. and Meyer, C. 2007, Understanding Customer Experience. Harvard Business Review, 85(6), 137, February 2007.

[21]. Tseng, M. M., Qinhai, M. \& Su, C. (1999). Mapping customers' service ex- perience for operations improvement. Business Process Management Journal, 5(1), 50-64.

[22]. Verhoef, P. C., Lemon, K. N., Parasuraman, A., Roggeveen, A., Tsiros, M. \& Schlesinger, L. A. (2009). Customer experience creation: Determinants, dynamics and management strategies. Journal of Retailing, 85(1), 31-41.

[23]. Zarantonello, L. and B. H. Schmitt (2010), 'Using the brand experience scale to profile consumers and predict consumer behavior'. Journal of Brand Management 17, 532-540

[24]. Zomerdijk, L. \& Voss, C. 2009. Service design for experience-centric services. Journal of Service Research, 13(1), 67-82.

[25]. Zomerdijk L.G and Voss C.A. (2010) Service design for experience-centric services, Journal of Service Research,

[26]. Breuer, R., Fanderl, H., Freundt, T., Maechler, N., Moritz, S., Fransje van der Marel, 2019, What matters in customer experience transformation, McKinsey\&Company, 9 July. Viewed 15 December at https://www.mckinsey.com/business-functions/marketing-andsales/our-insights/what-matters-in-customer-experience-cxtransformations

[27]. Bough, V., Neher, K., Breuer, R., Fanderl, H., 2017, Four Ways to Shape Customer Experience Measurement for Impact, McKinsey\&Company, 15 April. Viewed 15 December at https://www.mckinsey.com/business-functions/operations/ourinsights/four-ways-to-shape-customer-experience-measurement-forimpact

[28]. Investor Relation, 2019, KPN Strategic Priorities 2019-2021. Viewed 10 December, at https://ir.kpn.com/websites/kpn/English/1020/our2019-2021-strategy.html

[29]. Malim, G. 2018, Globe's Eclipse shares view of Amdocs Customer Experience Collaboration, 14 August. Viewed 15 December, 2019 at https://www.vanillaplus.com/2018/08/14/41141-globes-eclipseshares-view-amdocs-customer-experience-collaboration/

[30]. Media Realese, 2018, Telstra Sets New Strategy to Improve Customer Experience, 20 June. Viewed 20 December at https://www.telstra.com.au/aboutus/media/media-releases/Telstrasets-new-strategy-to-improve-customer-experience-simplifystructure-and-cut-costs

[31]. Sturman, C. 2018, Inside KPN's Journey to Personalised Connectivity, 9 March. Viewed 20 December at https://www.gigabitmagazine.com/company/inside-kpns-journeypersonalised-connectivity\# 